\title{
Fenômeno midiático contemporâneo
}

\author{
Orientador: Prof. Abimar Oliveira de Moraes
}

Pesquisador: Edmilton Neves Romão

Fonte: $\mathrm{CNPq}$

Introdução

Cada época expressa suas relações comunicacionais. Essa é uma verdade, que acompanha a humanidade e tudo que nela faz parte, há séculos. O homem como ser de cultura, portanto, exposto a tudo que ela lhe oferece, não é isento de mudá-la e nem tão pouco de deixar-se influenciar pela mesma em suas investidas, até porque, nas relações humanas há sempre intencionalidades culturais e comunicacionais engendradas por diversos mecanismos, seja, pelas redes sociais, programas televisivos, pelo uso dos instrumentos eletrônicos, ou pela roda de bate papo.

Esta segunda parte do trabalho cientifico, quer ser uma abordagem analítica do fenômeno midiático contemporâneo, levando em conta suas contribuições para a inter-relação com a mediação de conflitos. Sabemos que há limites que cercam essa relação. Levamos em conta também a imagem que a Igreja Católica tem em seus documentos em relação as novas redes de comunicações sociais. Percebe-se a importância da comunicação social, como forma que possibilita a unidade entre as pessoas.

Ao analisarmos o fenômeno midiático em seu conjunto de relações, percorremos o caminho das intencionalidades, ou seja, como o mesmo é capaz de mediar as relações entre as pessoas, como é capaz de mudar a cultura e dar a mesma uma conotação de novas relações. Tendo sempre um olhar critico e acolhedor a este fenômeno, fomos convidados a refletir a dimensão ética, que deve pairar sobre os meios de comunicação social, é comum nos documentos da Igreja Católica essa máxima de humanizar os meios de comunicação social, ou seja, devem-se ter critérios éticos que permeiam o seu uso.

\section{Objetivos}

Essa segunda parte da pesquisa, propõe uma aprofundada análise aos novos fenômenos midiáticos. Observando-os a luz dos documentos da Igreja, que os vê como "dom de Deus", desde que contribua para estreitar laços, daí o ponto de encontro com a primeira parte da pesquisa em relação à mediação de conflitos e as mídias. 